\title{
Peertechz
}

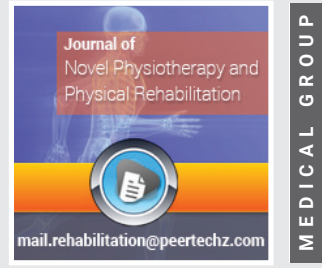

\section{The underestimated and under rated role of Physiotherapists during COVID-19 in Pakistan}

\author{
Hafsa Imtiaz Khokar* \\ Faculty of Pharmacy and Health Sciences, Department of Physiotherapy University of Balochistan, \\ Quetta
}

Received: 09 November, 2020

Accepted: 20 November, 2020

Published: 21 November, 2020

*Corresponding author: Hafsa Imtiaz Khokar, Faculty of Pharmacy and Health Sciences, Department of Physiotherapy University of Balochistan, Quetta, Tel: 00923063997878;

E-mail: Hafsa.physiotherapist@gmail.com

Keywords: Physiotherapy; Pakistan; COVID-19; Physical Therapy; Role

https://www.peertechz.com

Check for updates

\section{To the Editor}

Physiotherapists are healthcare professionals having direct contact with patients suffering from chronic disorders including COVID-19 [1]. Physiotherapists are also among the practitioners taking responsibility for the wellbeing of the COVID-19 and other infectious diseases management and outcomes thus sharing handsome amount of workload with healthcare systems [2].Physiotherapists possess a keen knowledge of COVID-19 and have hands on workforce planning during this pandemic. They know better when, where, and how to present their services for the betterment of patients suffering from corona viral infections. The important roles and responsibilities include Reducing Risk for Avoidable Hospitalization, Helping Offload Emergency Department Volume as Part of an Interdisciplinary Team and Meeting Post discharge Rehabilitation Demand for Survivors of COVID-19 [3]. During the recovery phase of most disorders physiotherapists along with other members of healthcare multidisciplinary team such as dieticians and psychologists play their part to improve health. COVID-19 in this respect is not an exception, where physiotherapists can play a vital role in rehabilitation process [4]. The challenges faced as acute care physical therapists during this pandemic are not new-historically, as a profession we have struggled to establish our role and value within our health systems. The positive changes seen within those systems that are actively engaging their rehabilitation departments to meet the needs of patients with COVID-19 can set the stage for a sustained paradigm shift in the roles and value of acute care physical therapy [5]. This evolution is twofold and includes: (1) maintenance of staffing levels needed to increase frequency and intensity of rehabilitation treatments in the acute care setting, and (2) investment in research to maximize the value of acute care physical therapy [5].
Before corona virus pandemic Pakistan was among the countries with scores of disabled population which proved to be a huge burden on poor healthcare system of the country [6]. As $70 \%$ of the population of this country live in remote villages away from basic rights of health. These individual are unable to access healthcare professionals including physiotherapists [7]. This can be a reason for deprived role and awareness of public regarding the role of physiotherapists in containment of COVID-19 infections and improving post COVID life of those infected.

A study during 2020 conducted in Pakistan among patients expressed positive attitude regarding the role of Physiotherapists in Pakistan including COVID-19.Patients were found to be more satisfied after experiencing physiotherapy services rather than before, without the professionals services of Physiotherapists [8]. The key professional roles of physiotherapists including acute hospital care such as respiratory intervention and rehabilitation is ignored in Pakistan due to poor healthcare structure and compromised literacy rate of individuals. As in the developed countries special assistance and attention must be paid to enhance the role of Physiotherapists in uplifting the quality of life of patients infected with novel corona virus in Pakistan [9].

Governmental and non-governmental organizations (NGOs) shall play their part in awareness and knowledge of general public about the roles of physiotherapists in post COVID rehabilitations processes. Such steps will help the country fight this pandemic more professionally than ever thus enhancing the quality of life of Pakistani nationals with decreasing burden on healthcare systems of the country.

\section{References}

1. Thomas P,Baldwin C, Bissett B, Boden I, Gosselink R, et al. (2020) Physiotherapy 
management for COVID-19 in the acute hospital setting: clinical practice recommendations. J Physiother 66: 73-82. Link: https://bit.ly/35P2xGt

2. Alami S, Desjeux D, Lefèvre-Colau MM, Boisgard AS, Boccard E, et al. (2011) Management of pain induced by exercise and mobilization during physical therapy programs: views of patients and care providers. BMC musculoskeletal Disord 12: 172. Link: https://bit.ly/3kOAXxk

3. Falvey JR, Krafft C, Kornetti D (2020) The essential role of home-and community-based physical therapists during the COVID-19 pandemic. Phys Ther 100: 1058-1061. Link: https://bit.ly/2IROk2D

4. Smith JM, Lee AC, Zeleznik H, Coffey Scott JP, Fatima A, et al. (2020) Home and community-based physical therapist management of adults With post-intensive care syndrome. Phys Ther 100: 1062-1073. Link: https://bit.ly/3pNCtmY

5. Keeney T (2020) Physical therapy in the COVID-19 pandemic: forging a paradigm shift for rehabilitation in acute care. Phys Ther 100: 1265-1267. Link: https://bit.ly/3fhKBXZ

6. Maarefvand $M$, Hosseinzadeh S, Farmani O, Safarabadi Farahani A Maarefvand M, et al. (2020) Coronavirus outbreak and stress in Iranians. Int J Environ Res Public Health 17: 4441. Link: https://bit.ly/2UGWb5A

7. Ogilvie I (1989) Rehabilitation in Pakistan: Where there is nothing, where do you start? Physiotherapy 75: 354-357. Link: https://bit.ly/3kOMFrF

8. Ahmed MA, Ahmed U, Rizwan N, Tauqeer S, Javed H (2020) Assessing the Services Quality: Expectations And Perceptions Of Patients Receiving Physiotherapy Services At Teaching Hospitals In Lahore, Pakistan. Khyber Medical University Journal 12: 143-148. Link: https://bit.ly/3kOCOxg

9. Rathore FA, New PW, Iftikhar A (2011) A report on disability and rehabilitation medicine in Pakistan: past, present, and future directions. Arch Phys Med Rehabil 92: 161-166. Link: https://bit.ly/3kPabEQ
Discover a bigger Impact and Visibility of your article publication with

Peertechz Publications

\section{Highlights}

* Signatory publisher of ORCID

* Signatory Publisher of DORA (San Francisco Declaration on Research Assessment)

* Articles archived in worlds' renowned service providers such as Portico, CNKI, AGRIS, TDNet, Base (Bielefeld University Library), CrossRef, Scilit, J-Gate etc.

* Journals indexed in ICMJE, SHERPA/ROMEO, Google Scholar etc.

- OAI-PMH (Open Archives Initiative Protocol for Metadata Harvesting)

- Dedicated Editorial Board for every journa

* Accurate and rapid peer-review process

* Increased citations of published articles through promotions

* Reduced timeline for article publication

Submit your articles and experience a new surge in publication services (https://www.peertechz.com/submission).

Peertechz journals wishes everlasting success in your every endeavours.

Copyright: @ 2020 Khokar HI. This is an open-access article distributed under the terms of the Creative Commons Attribution License, which permits unrestricted use distribution, and reproduction in any medium, provided the original author and source are credited. 